\title{
CERAMIC WATER DROPPERS IN THE COLLECTION OF THE PRINCESSEHOF: FANCY SHAPES, SURPRISING USES
}

The Princessehof Museum collection includes many spectacular objects, but also many minor masterpieces created for the appreciation of the connoisseur. Modest in size their shapes are surprising and their use is varied. Water droppers, for example. Every educated Chinese, be it 2000 years ago or today, had and has to use a number of objects when writing. Traditionally the four treasures (sibao) on a Chinese scholar's desk are ink, an inkstone, a brush and paper. Ink was made from pinewood soot and organic glue. To these basic ingredients, aromas or perfumes like musk were often added. To obtain a usable shape the mixture was pressed into moulds, and its water content evaporated as it solidified into inksticks. To use it, tiny quantities of water were dropped onto the plain surface of the inkstone before the inkstick was rubbed on it, and to control the amount of water the Chinese invented the water dropper. Water droppers (shuizhu) were original known as 'water dropper for the inkstone' (yandi).

A 'classical' water dropper has two openings: one for water and one for air. The dropper is filled with water through the opening on the top, which also functions as an air vent: the release or dosage of water is regulated by carefully opening or closing this little air vent with the index finger. Raising the finger from the hole releases the vacuum, allowing water to drop out. Usually a small amount of water is applied to the inkstone before the bottom end of the inkstick is ground slowly on the grinding surface. Particles from the inkstick dissolve in the water to form ink. Different shades of ink might be required for calligraphy or painting, from thick black ink to light gray hues. By carefully dosing the water, various shades of ink can be prepared according to the consistency the artist needs. More water is gradually added during grinding to increase the amount of ink produced, the excess flowing into a well or reservoir in the inkstone where it will not evaporate as quickly as on the flat grinding surface. The Chinese grind their ink in a circular motion with the end of the inkstick flat on the surface, while the Japanese rub one edge of the end of the inkstick back and forth. Calligraphy or a painting made with ink ground in the traditional way on an inkstone looks rhythmic, lively and spirited; with bottled liquid ink the results are rather monotonous.

Ceramics ranked low among the materials considered desirable for the often highly sophisticated objects comprising the four treasures, yet of the small vessels intended to contain water, porcelain and stoneware objects far outnumber those in other materials like jade or bamboo. Water droppers are usually very small, most of them less than five centimetres in diameter, and their wide variety of charming shapes provides much aesthetic pleasure. This small selection of water droppers from the frot $_{\text {2023 }}$ 12:31:33pM 
Fig. 2

Water dropper in the shape of a threelegged toad, Qingbai stoneware, $6.1 \times 8 \mathrm{~cm}$., China, 12th - 14th century, Museum het Princessehof, GMP 1981-124

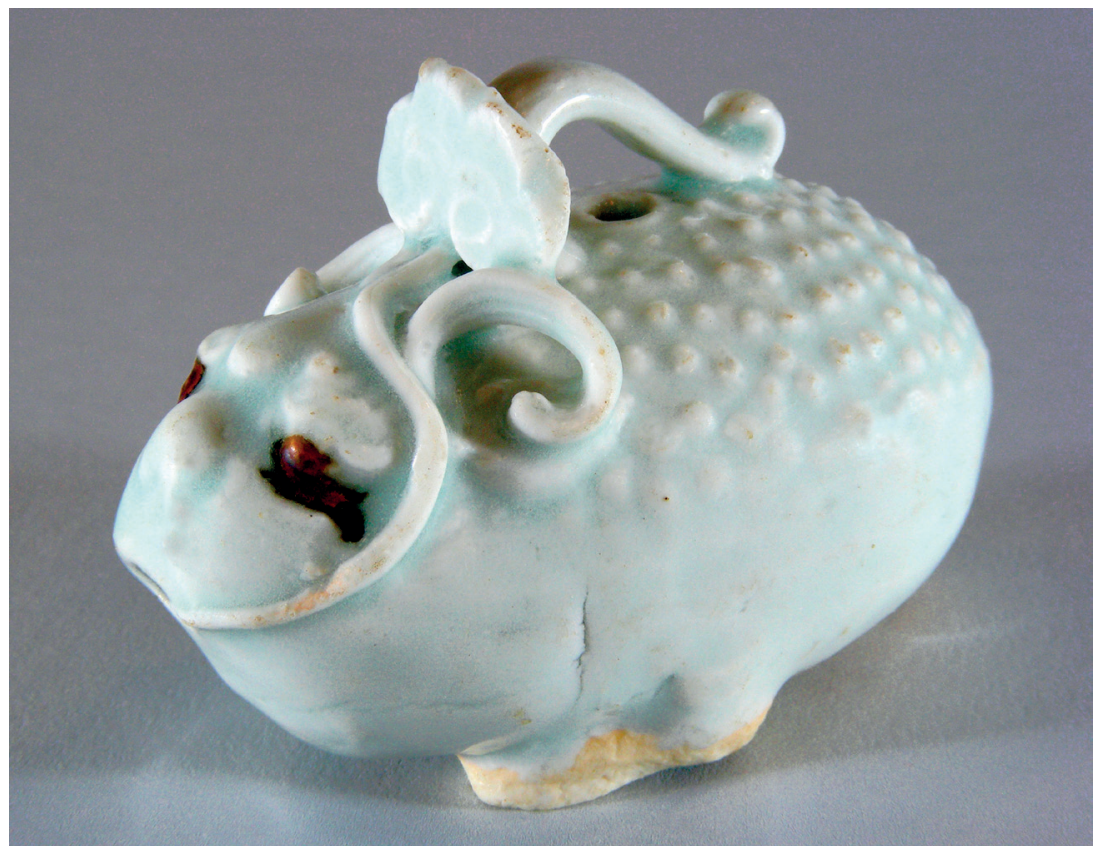

Princessehof Museum collection includes examples made in China, Vietnam and Thailand. There are zoomorphic shapes such as frogs, threelegged toads, elephants, ducks and turtles. Most of these zoomorphic droppers have a small hole on the top while the spout is hidden in the animal's mouth.

\section{For the scholars desk: water droppers from China}

The oldest water dropper in the Princessehof Museum collection is shaped as a frog (fig. I). It is dated to the Western Jin dynasty (265-3I7). The frog's head and limbs were modelled and applied to the body. There is a cylindrical spout on the back and a small hole in the mouth. The decorations are impressed and incised. This small vessel, made of high-fired stoneware and covered with a fine iron oxide, greenish glaze, represents a 'proto-celadon', and is typical of Yue wares. Yue wares are named after the place where they were made, a region in Zhejiang province that was known as the Kingdom of Yue. Several hundred kilns have been discovered there. Yue wares were made as early as the 3 rd century as a local product copying contemporary bronze forms. Because of their high status Yue wares - including water droppers - were used at court, by the elite and by scholars. The Yue kilns made small droppers in naturalistic forms like rams or lions, but frog shapes were very popular in southern China, because frogs represent fertility and are associated with rain and moisture, particularly in Southern China, Vietnam and other parts of Southeast Asia. ${ }^{2}$ 


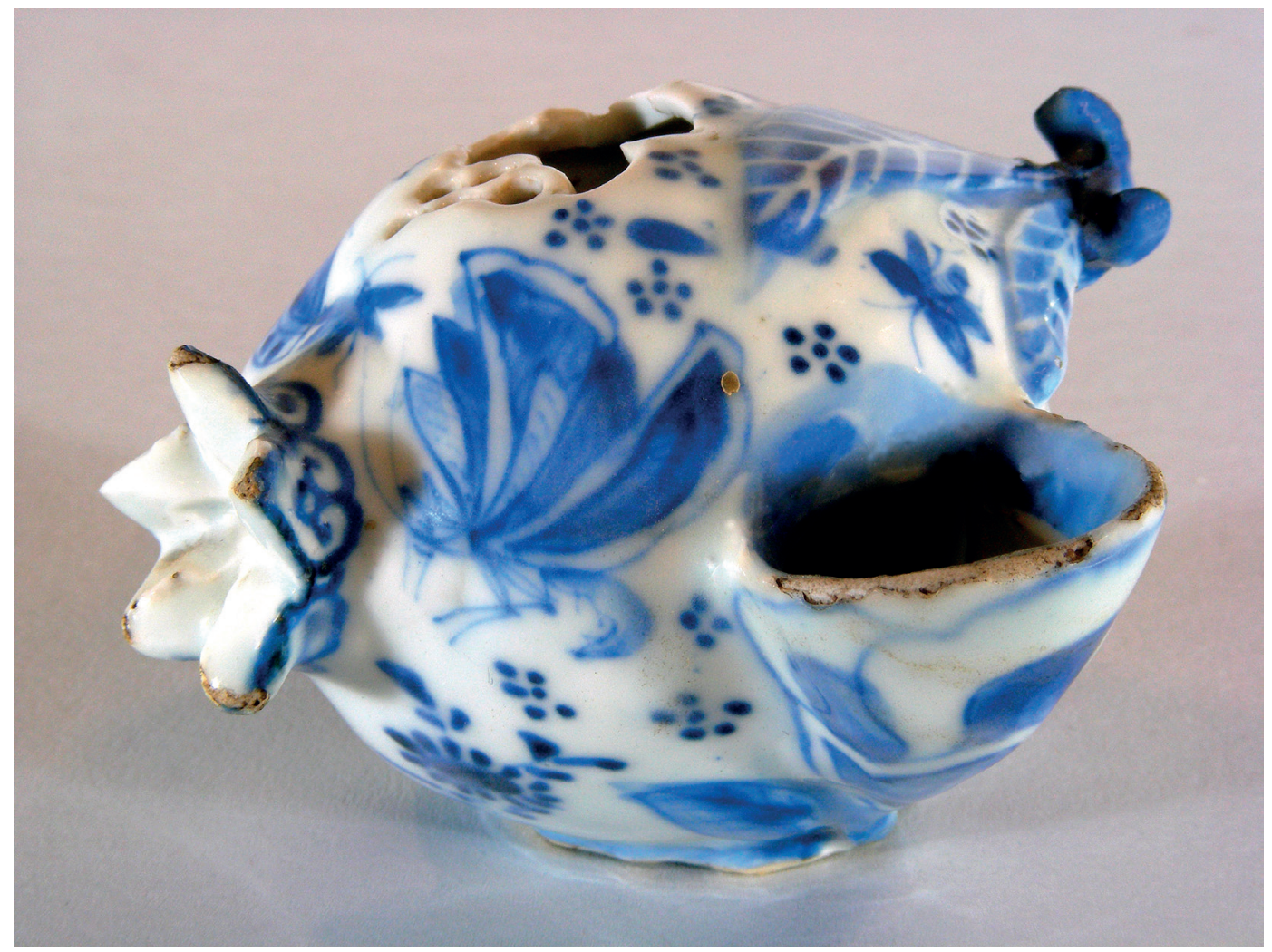

Fig. 3

Water dropper in the shape of a pomegranate, Jingdezhen porcelain, decorated in cobalt blue, 6 × $10 \mathrm{~cm}$., China, Qing dynasty (1644-1911), 18th century, Museum het Princessehof, NO 2487. On loan from the Ottema-Kingma Stichting
The dropper in the shape of a toad (fig. 2) can be dated some thousand years later, between the I2th to I4th centuries. It is made of stoneware and is of the qingbai type, literally 'greenish' or 'bluish white', also called yingqing 'shadowy blue', a glaze that started to be made during the Song dynasty (960-I279). It is an amusing small object. The potter seemed to have enjoyed imitating the toad's warty skin and irregular dark brown eyes, the result of iron oxide breaking through the glaze. Was it an accident, or an intentional joke by the potter? Oddly enough, the toad only has three legs. In China, a three-legged toad is the 'money-toad', a charm for prosperity. A toad that seems to spit coins accompanies the Taoist immortal Liu Hai, who is often depicted with a string of cash on a long cord. What a pleasure it must have been for a Chinese scholar of long ago to have this charming object on his desk!

The water dropper shown in figure 3, decorated in cobalt blue with butterflies and a ruyi sceptre (symbolising power and good fortune), and with modelled leaves and sprigs, is shaped as a pomegranate. Pomegranates are not only beautiful fruits; when half open, they reveal numerous seeds in the auspicious colour red. In Chinese the word seed, $z i$, is homophonous with $z i$, meaning sons. Thus the pomegranate became a well-established symbol of fertility and of the wish for abundant male offspring. As a design on porcelain it was most popular during the Ming (I268-I644) and Qing (I644-I9II) dynasties. The opening on the top of this water dropper is decorated with openwork; water can be dropped or

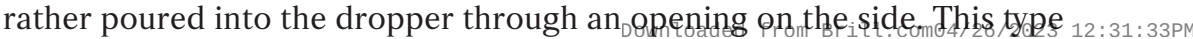


Fig. 4

Left: Water dropper in the shape of a peach,

Dehua porcelain,

undecorated, $5.4 \mathrm{X}$

9 cm., China, Qing

dynasty (1644-1911),

18th century, Museum

het Princessehof, NO

1276. On loan from

the Ottema-Kingma

Stichting

Right: Water dropper

or flask in the

shape of a squirrel,

Dehua porcelain,

undecorated, $3.3 \times 2.3$

$x 7$ cm., China, Qing

dynasty (1644-1911),

19th century, Museum

het Princessehof, NO

974. On loan from

the Ottema-Kingma

Stichting. Acquired

from CT Loo, 19. April

1933, no. 16.539

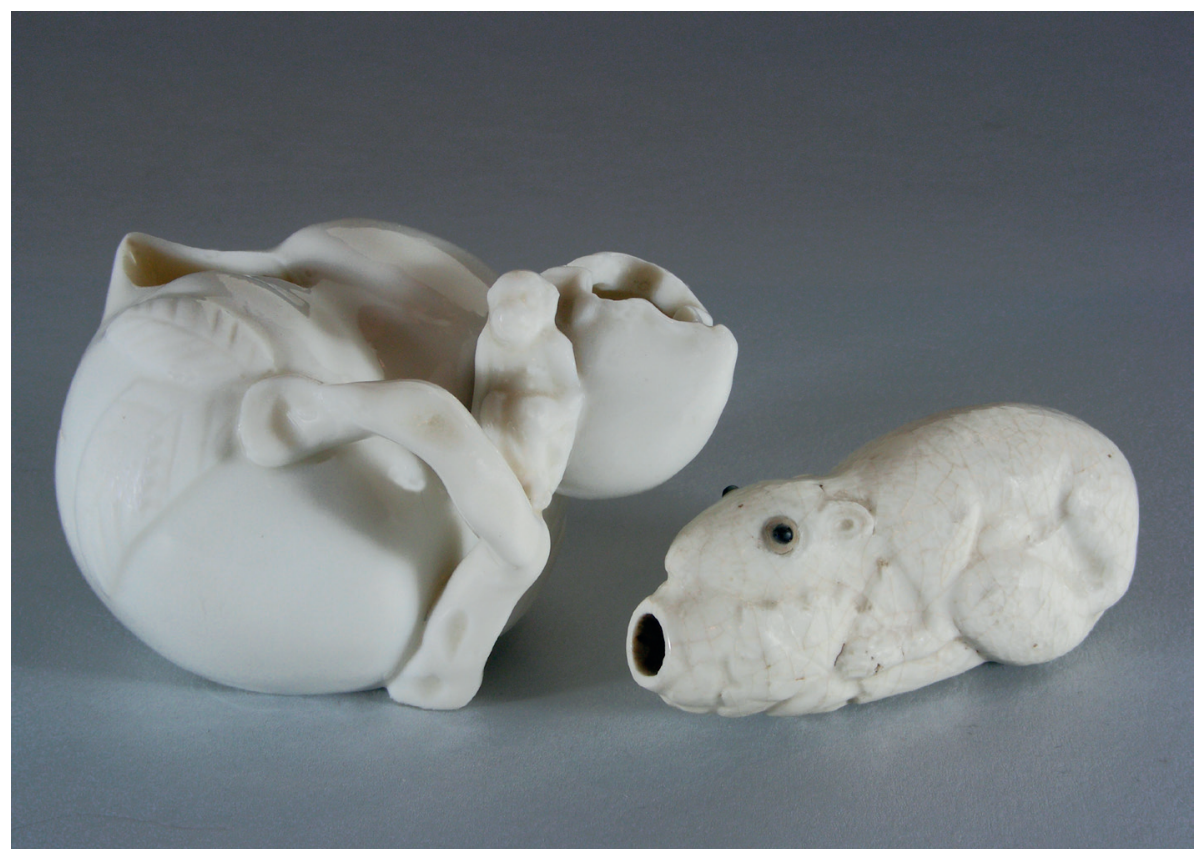

of water dropper could not be used to dose small amounts or drops of water, but could have been used to pour water onto the inkstone. ${ }^{3}$ Or was it just a charming decorative object?

The peach-shaped dropper on the left in figure 4 is another amazingly fine miniature sculpture. The handle is modelled as a branch. Surprisingly, a tiny sitting monkey is attached to the body. The peach shape in pure white porcelain is not only very pleasing and elegant, but also auspicious. It is associated with the peaches grown in the orchards of Xiwangmu, Queen Mother of the West, on the fabled Kunlun Mountains, the mountain paradise of Chinese tradition believed to be located in western China. Still today, peaches are a perfect birthday present in China, a wish for longevity and immortality. This lovely dropper was made in the kilns of Dehua, a place in the present southern province of Fujian. Starting in the Song dynasty, they specialised in pure white, unpainted wares for the Chinese market and later, in the I7th and I8th centuries, also for export. This one was made for a Chinese scholar's desk. The small object shown on the right in figure 4 has the lively shape of a squirrel, nibbling grapes. This motif of a squirrel eating grapes is a wish for longevity. The character for Squirrel, pronounced song in Chinese, has the same sound as song, or pine tree, a symbol of long life; and grapes, or tao, are associated with the Peaches of Immortality from Xiwangmu's orchards, also pronounced tao. It could be a miniature flask or a dropper, but with just one small opening below the animal's head, we cannot be certain of its use. 


\section{Miniature droppers from Vietnam}

Fig. 5

Group of miniature water droppers,

stoneware, painted in cobalt blue, Vietnam, late 15th or early 16th century, Museum het Princessehof.

FLTR: Bird, $6.5 \times 7 \mathrm{~cm}$. (GMP 1981-140), given by Mrs. Coulingh in 1981, probably collected in Indonesia; Elephant, $4 \times 6 \mathrm{~cm}$., (OKS 1968-10), acquired in 1968 from Sotheby's, London. On loan from the Ottema-Kingma Stichting; Toad, $3 \times 5$ cm., (OKS 1968-009), acquired in 1968 from Sotheby's, London. On loan from the OttemaKingma Stichting
The Princessehof collection includes a number of early Vietnamese water droppers in the shape of miniature animals: a bird, an elephant, and a toad (fig. 5). The bird and the toad have two openings, one on the back and one as the mouth, or beak, but the elephant has just one opening on the back. Dated to the late i5th to early i6th century, they are moulded and decorated in blackish cobalt blue. Details such as eyes, feathers and fur are suggested with a few simple lines or dots. They are charming in a naïve way and look - well - like toys, but the opening on the back and the opening designed as the mouth indicate that they are droppers. This still leaves the question, how were these droppers used? They were certainly not part of the four treasures on a Chinese scholar's table. And the small elephant? With just one opening it isn't a dropper, so what was it used for?

Let us first establish where and how these miniatures were made. The late I5th and early I6th centuries were a golden age for Vietnamese ceramics. The Chinese government had prohibited the export of Chinese ceramics, and many Chinese potters had emigrated to Vietnam in search of work, bringing with them their skills which they shared with their Vietnamese counterparts. The Vietnamese moved quickly to fill the gap in the market. The extent of this trade became apparent with the accidental discovery of shipwrecks such as the fully loaded Chinese merchant vessel discovered

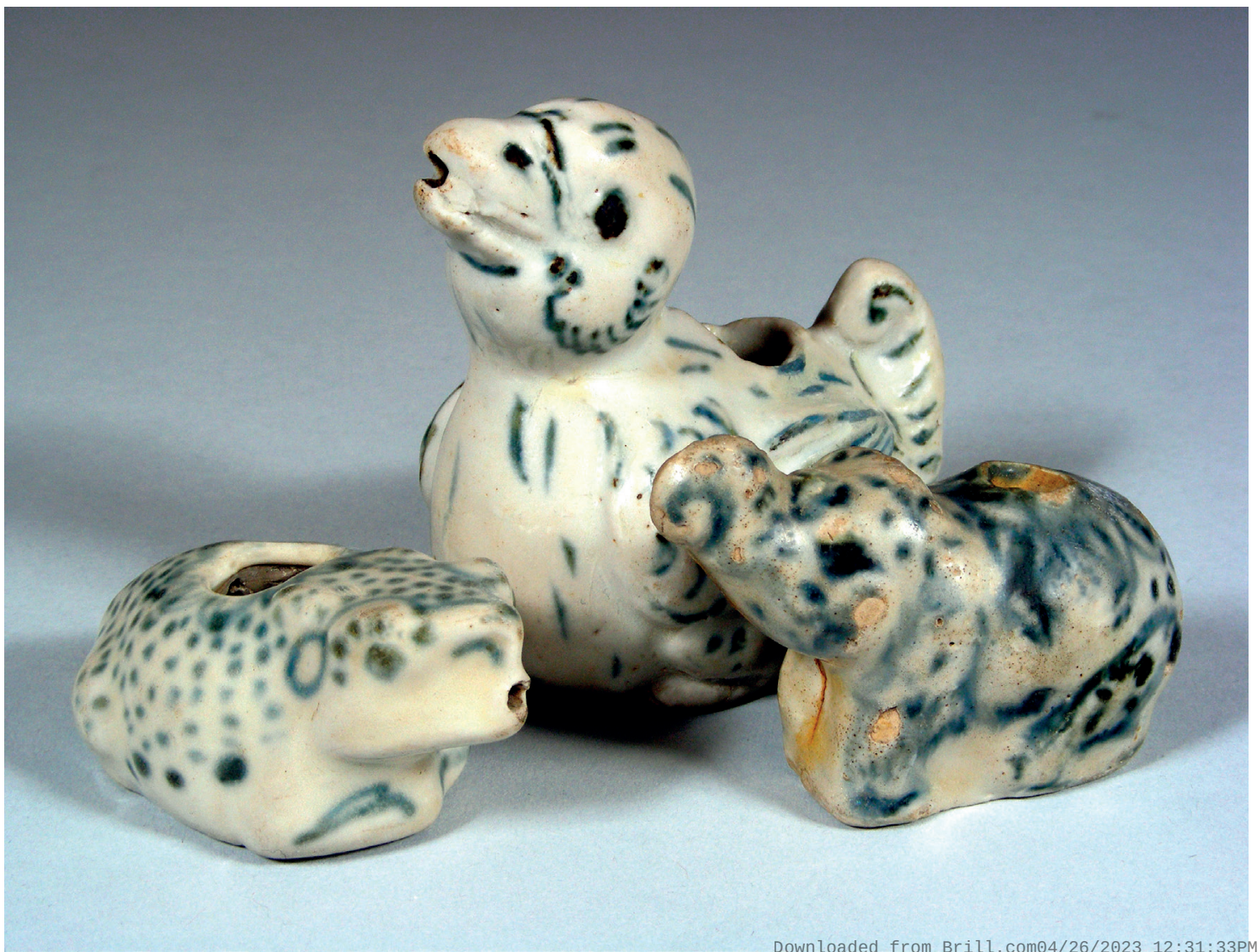


Fig. 6

Container for lime

(?) in the shape of a turtle, stoneware, painted in cobalt blue, $3.5 \times 6.5 \times 8.4 \mathrm{~cm}$., Vietnam, Thanh Hoa, late 15th or early 16th century, Museum het Princessehof, GMP 1962-04

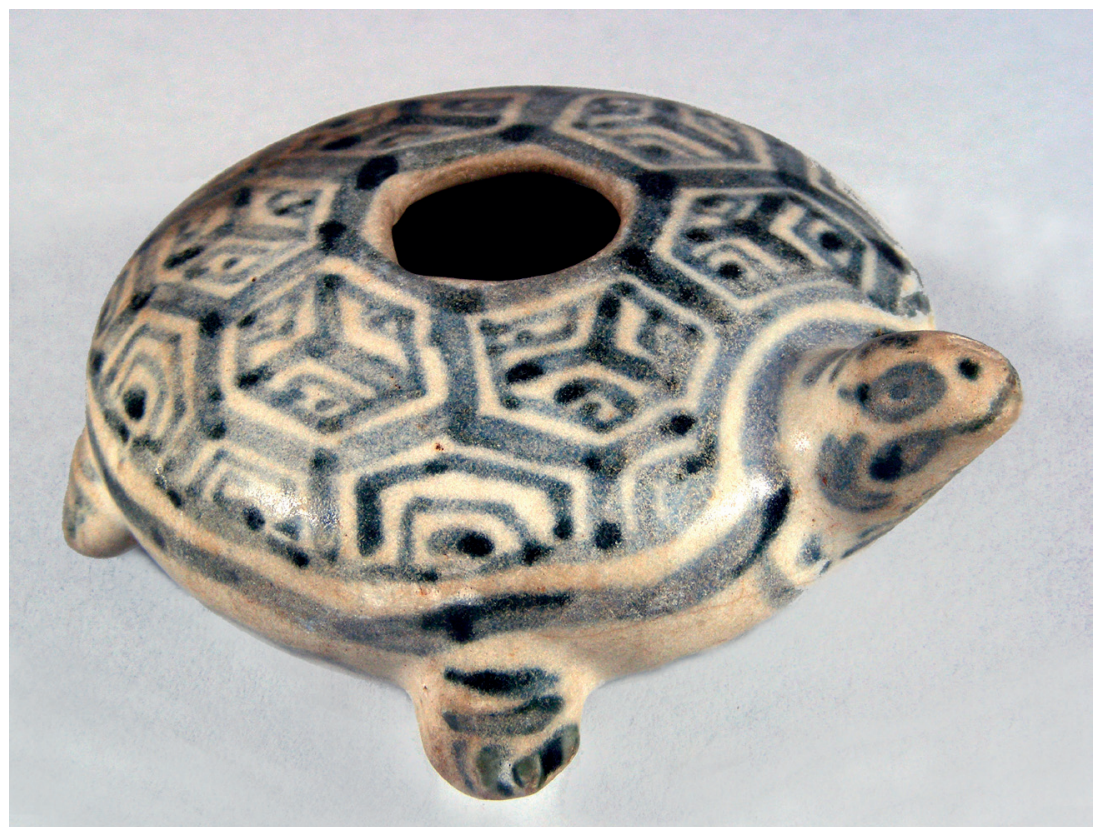

off Hoi An, Vietnam, in I993-I994. ${ }^{4}$ The ship, dated late I5th to early I6th century, was loaded with hundreds of thousands of blue and white porcelains, made in the kilns of Hai Duong, near the port of Hai Phong. The Hoi An porcelain cargo had a great variety of styles and quality, and included small animal-shaped droppers similar to the ones presented here.

Vietnamese ceramics were traded to Thailand and Burma, as well as to the Philippines and Indonesia where, from the mid-I2th to the I5th century, i.e., in pre-Christian and pre-Islamic times, they were status objects that were interred with their owners. Most pieces remained buried until the 2oth century, when increasing demand from collectors led to them being excavated from gravesites. Their use was probably similar to that of small jarlets, standard trade items for the Southeast Asian market that functioned as burial furniture or as vials for perfume, cosmetics, medicines and charms. This would explain why the elephant and the turtle have just one opening on the back - they were not intended to be used as droppers.

The turtle-shaped water dropper was potted and decorated with more care (fig. 6). The head, the four legs and the tail are attached to the body. There is a round opening on the back, but it lacks a spout. The animal's shell is painted in the aptly named 'turtle back' motif. Turtle shapes were also very popular in Southeast Asia. A small ceramic turtle, also with an opening on the back, made in Cambodia in the isth century, was probably used as a container for lime. ${ }^{5}$ This could also explain the functions of the small zoomorphic vessels with just one oppening, dike the elephant in $n_{3}$ 12:31:33рм 


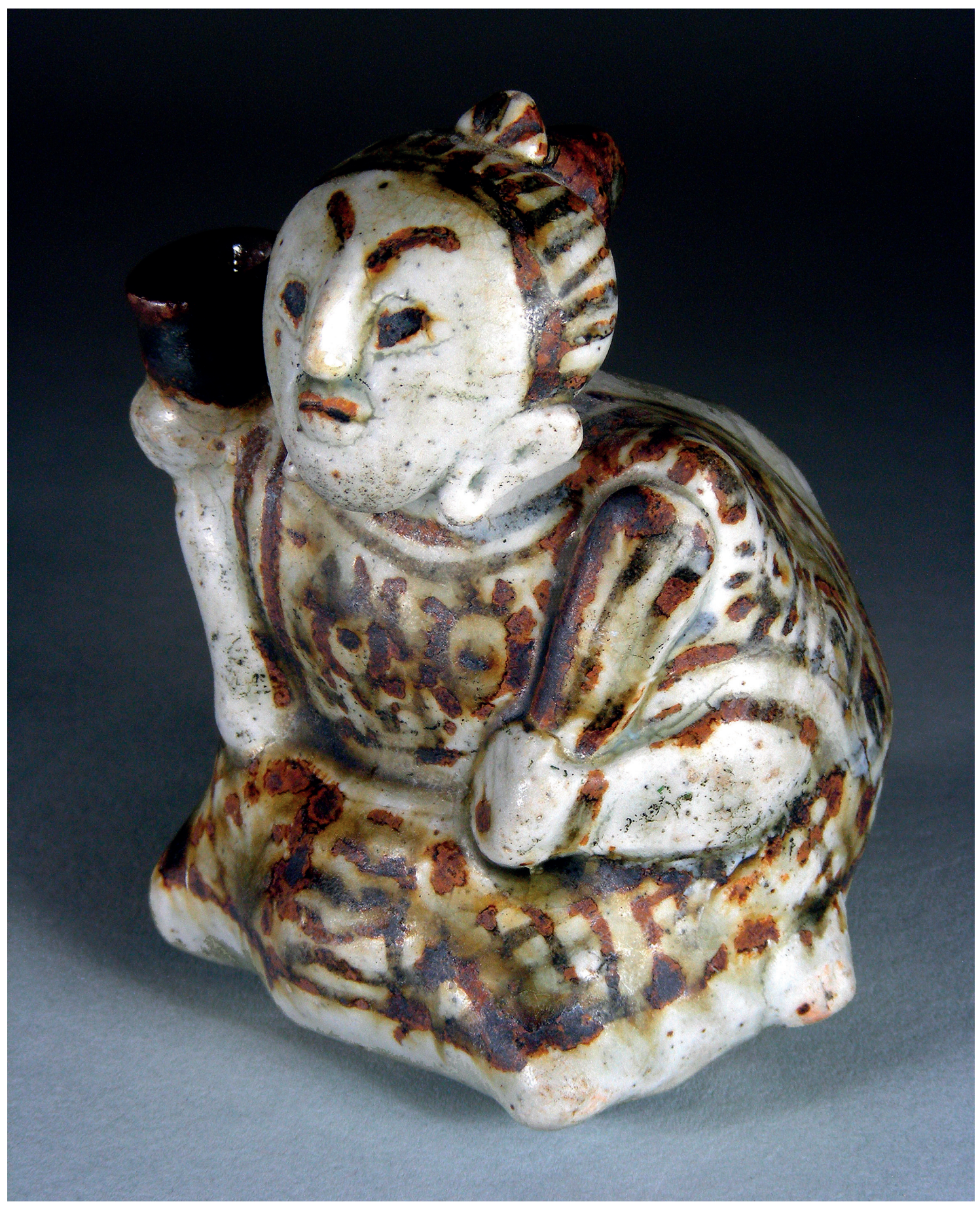

Fig. 7

Small vessel in the shape of a

hunchbacked man, stoneware, decorated

with iron oxide, $8.5 \times 6.5 \times 6 \mathrm{~cm}$.,

Thailand, Sawankhalok, Si Satchanalai, late 15th or early 16th century, Museum het Princessehof, GMP 1947-001 
figure 5. The use of betel nuts as a medicine and mild stimulant has always been widespread in Southeast Asia. Usually chewed, a few slices of Areca nut are wrapped in a betel leaf along with lime (calcium hydroxide) and spices such as clover or cardamom for extra flavour. The lime was often kept in small, fancy jars and pots.

\section{A 'magical' dropper from Thailand}

The last stop on our journey exploring Asian water droppers is Thailand. The Princessehof Museum has a small vessel in the shape of a hunchbacked man, inventoried as a 'water dropper' (fig. 7). This shape differs from all the zoomorphic and other shapes found in China and Vietnam. Made of stoneware, it is painted in iron oxide in a style called 'brown and pearl', and was probably manufactured in the Sawankhalok (Si Satchanalai) kilns in Northern Thailand. These kilns produced an astonishingly wide variety of wares ranging from large water jars to miniature figures, which became a hallmark of Sawankhalok. These miniature wares were widely traded throughout Southeast Asia. Examples have been found at burial sites in Angkor and throughout the Philippines and Indonesia. Some are known from North Sumatra, and a wider range of these figures was found in South Sulawesi, where the present dropper was acquired. ${ }^{6}$

The kneeling man wears a sarong with floral and geometrical motifs. His hair is arranged in a chignon. In his right hand he holds a pot that serves as the spout; in his left he has an object that is probably a flywhisk, an attribute of magicians. The hunchbacked man therefore probably represents a sorcerer-magician. ${ }^{7}$ The use of these objects is unknown, but because they were found in graves, they were probably used in the same way as the Vietnamese animal-shaped droppers discussed above.

Water droppers may not count among the most spectacular pieces in a museum collection. However, these miniatures represent a fascinating combination of functionality with a rich creativity in inventing amusing shapes to adorn the scholar's desk. In Chinese they are suitably called guwan, or 'curios' (literally "old plaything").

- Eva Ströber is currently curator of Oriental ceramics at the Princessehof National Museum of Ceramics, Leeuwarden. Before coming to the Netherlands she worked as curator of Augustus the Strong's collection of Oriental porcelain for the Dresden Porcelain Collection. Her academic background is in Chinese studies, Oriental art history and comparative religion.

\section{LIT ERAT URE}

John Ayers, The Baur Collection Geneva: Vol. I Tang and Sung Period (with Korean and Thai Wares) and Vol. II Ming Porcelains and Other Wares, Geneva, I969.

Sandra Borstlap, Keramiek uit Vietnam, Museum het Princessehof, Leeuwarden 1993.

Larry Gotuaco, Rita C. Tan, Allison I. Diem, Chinese and Vietnamese Blue and White Wares found in the Philippines, Bookmark, Makati City, Philippines, 1997. 
John Guy, 'Vietnamese Ceramics from the Hoi An Excavation: The Cu Lao Cham Ship Cargo', Orientations, (Sept. 2000), pp. 125-8.

Masha Karatas, Bartle van der Heyde en Hamzah Daeng Nangka, 'Twee Kunstliefhebbers in de Nadagen van Nederlands-Indie', Keramika 3 (200I), pp. 20-5, uitgave Keramiekmuseum Princessehof, Leeuwarden.

Jackie Menzies (ed.), The Asian Collections: Art Galleries of New South Wales, Art Gallery of New South Wales, Sydney, 2003.

John N. Miksic (ed.), Southeast Asian Ceramics: New Light on Old Pottery, Southeast Asian Ceramic Society, Singapore, 2009.

Dick Richards, South-East Asian Ceramics: Thai, Vietnamese and Khmer, Oxford University Press, Oxford, 1995.

Dawn F. Rooney, Khmer Ceramics: Beauty and Meaning, River Books Press, Bangkok, 2010

Eva Stroeber, Symbols on Chinese Porcelain: Io.ooo Times Happiness, Arnoldsche Art Publishers, Stuttgart, 20II.

Shelagh J. Vainker, Chinese Pottery and Porcelain: From Prehistory to the Present, British Museum, London, I99I.

\section{NOTES}

* All photographs by Lukas Kraemer.

I There are a few comparable frog-shaped droppers in the British Museum, see Vainker I99I: 50-I, fig. 37.

2 Bronze 'frog drums' were already being used to summon rain during the Dong Son culture, from around $500 \mathrm{BC}$.

3 A comparable dropper in the shape of a peach and of finer quality is in the Baur Collection, see Ayers 1969: vol. II, no. A 224.

4 For the Hoi An shipwreck, see Guy 2000.

5 For a Khmer ceramic turtle dated to the I3th century, see Rooney 20I0: I43, cat. no. 153.

6 Hamzah Daeng Nangka, from Celebes (now Sulawesi), gave the water dropper to the Princessehof Museum in 1947. He was a collector and dealer and operated a small shop. The dropper was excavated near Makassar, now Ujang Panjang. See Karatas 200I.

7 With this interpretation I follow Miksic 2009: II3. 